\title{
Segmentation-Based Fractal Texture Analysis (SFTA) to Detect Mass in Mammogram Images
}

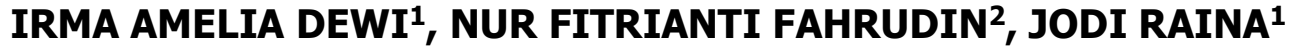

${ }^{1}$ Program Studi Informatika, Institut Teknologi Nasional Bandung, Indonesia

${ }^{2}$ Program Studi Sistem Informasi, Institut Teknologi Nasional Bandung, Indonesia

Email: irma_amelia@itenas.ac.id

Received 17 November 2020 | Revised 20 Desember 2020 | Accepted 7 Januari 2021

\begin{abstract}
ABSTRAK
Di Indonesia, kasus kanker paling banyak adalah kanker payudara yaitu 58.256 kasus atau 16,7\% dari total 348.809 kasus kanker. Dibutuhkan suatu sistem yang dapat membantu pakar untuk mendeteksi kanker payudara pada wanita dengan mengindentifikasi citra mammogram. Keabnormalan dapat dideteksi dari massa pada mammogram yaitu area dengan pola tekstur dan bentuk serta batas tertentu. Berdasarkan hal tersebut maka dibuat sebuah sistem yang dapat mendeteksi massa kanker pada citra mammogram menggunakan Segmentation-Based Fractal Texture Analysis (SFTA). Tahapan pertama akuisisi citra, dilanjut dengan segmentasi menggunakan k-means dan thresholding. Hasil dari segmentasi citra dilakukan tahapan morfologi menggunakan opening dan masking. Setelah itu dilakukan ekstraksi fitur SFTA, dan klasifikasi Support Vector Machine (SVM). Hasil pengujian penelitian ini didapatkan nilai akurasi sebesar 90\%, presisi sebesar $87,75 \%$, recall sebesar 93,33\%dan f1-score $90,32 \%$ dengan nilai number of threshold (nt) SFTA adalah 3
\end{abstract}

Kata kunci: mammogram, SFTA, kanker payudara, klasifikasi

\begin{abstract}
In Indonesia, the most cancer cases were breast cancer, namely 58,256 cases or $16.7 \%$ of the total 348,809 cancer cases. A system is required to assist the expert in detecting breast cancer in women by identifying mammogram images. Abnormalities in a mammogram are determined in part of texture with a particular form and specific limit, usually called a 'mass.' Image acquisition is perceived as the first step, followed by segmentation using the k-means and the thresholding. Image segmentation undergoes the morphological analysis steps using opening and masking methods, after feature extraction processing by SFTA, using Support Vector Machine (SVM) for classification processing. The obtained research result revealed an accuracy value of $90 \%$, a precision value of $87.75 \%$, a recall value of 93.33\%, and an F1-Score of $90.32 \%$, with the number of thresholds (nt) of SFTA amounting to 3.
\end{abstract}

Keywords: Breast cancer, Mammogram, Classification, SFTA 
Dewi, dkk

\section{INTRODUCTION}

Cancer is one of the deadliest diseases globally, with a growth rate and excessive cell growth and uncontrolled (Arafah \& Notobroto, 2017) (Larasati \& Prawira, 2018) (Supriyanti, 2014). Breast cancer is one of the examples. It usually grows in the lobule cells, namely the glands that produce milk and the ducts (Biswas et al., 2016) (Fajrin et al., 2015). According to the World Health Organization in 2018, around 627,000 women died from breast cancer or $15 \%$ of every death caused by breast cancer in women. In Indonesia, it shows that most cancer cases are breast cancer, with a total case of $58,256=$ or $16.7 \%$ of 348,809 cases of cancer.

Mammography is a special screening and radiological examination process using a low-dose of x-rays (Nur, 2014) (Listia et al., 2014) to identify abnormalities in the breast such as cancer (Junita, 2017). The result of mammography is called a mammogram. The presence of a mass indicates the abnormality in the mammogram image. Diagnosing breast cancer on mammogram images requires the skills and experience of a radiologist. Computer-Aided Diagnosis (CAD) is a system that can be used as a problem solver in diagnosing and identifying breast cancer (Nababan et al., 2017), where CAD is expected to help radiologists detect breast cancer. CAD has two stages: segmentation on mammogram images and a step for detecting breast cancer (Hariraj et al., 2017).

Based on this background, this study designed a system to detect masses in mammogram images using the Segmentation-Based Fractal Texture Analysis (SFTA) method. Several studies have been performed to detect mammogram masses, such as (Setiawan \& Putra, 2019) using the k-means method for segmentation, Gray Level Co-Occurance Matrix (GLCM) for feature's texture extraction, and SVM for classification. The results obtained an accuracy value of $80 \%$ for the classification of normal or abnormal mammogram images. Research by (Suresh et al., 2019) conducted segmentation with ARKFCM and hybrid for feature extraction with GLCM and Histogram of Oriented Gradients (HOG) with DNN classification obtained an accuracy value of $98.8 \%$.

The previous study's weakness lies in the use of GLCM that extracted the value from the area of mass, and they only used four value features. Research (Suresh et al., 2019) conducted a hybrid GLCM with HOG to extract cancer cells' optimal feature value. The HOG calculates the gradient orientation and illumination of the edges or boundaries. The cancer cell area is called the mass, where there are textural patterns with specific shapes and borders (Junita, 2017). The texture feature can be extracted from certain areas and borders on the mass with the SFTA method based on the fractal value on an image's edge (Öztürk \& Akdemir, 2018). STFA also produced the mean value of the grey area (pixel counting).

A preliminary study related to the SFTA method was also conducted (Costa et al., 2012). This study compares the feature extraction methods used, namely GLCM, Gabor filter, and SFTA for image retrieval and image classification. These studies show that the SFTA algorithm is simple but effective because SFTA extraction is 3.7 times faster than Gabor filters and 1.6 times faster than GLCM. Research by (Öztürk \& Akdemir, 2018) compared the texture feature extraction and histopathological image classification. The study results were SFTA feature extraction, and SVM classification resulted in better accuracy than the others at $94 \%$.

Based on the review of the literature, this study aims to measure the accuracy of the SFTA method in obtaining the fractal dimension, mean, and area features of the mammogram mass and applying the Support Vector Machine (SVM) method to classify the mammogram mass 
image into normal or abnormal image classes which indicate the presence of cancer cells or tumors

\section{METHODOLOGY}

In this study, the mammogram dataset images came from MIAS (Mammographic Image Analysis Society) and CBIS-DDSM (Curated Breast Imaging Subset of Digital Database for Screening Mammography). The number of training images consists of 400 images with 215 normal images and 185 abnormal images with sample images, as shown in Figure 1 . The test images were performed with 30 images consist of 15 normal and 15 abnormal. The image size is $1024 \times 1024$ saved in .pgm and .png format with right or left position. The process flow can be seen in Figure 2.

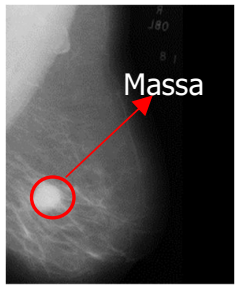

(a) Abnormal Figure 1

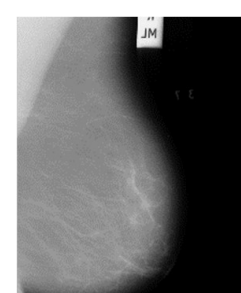

(b) normal

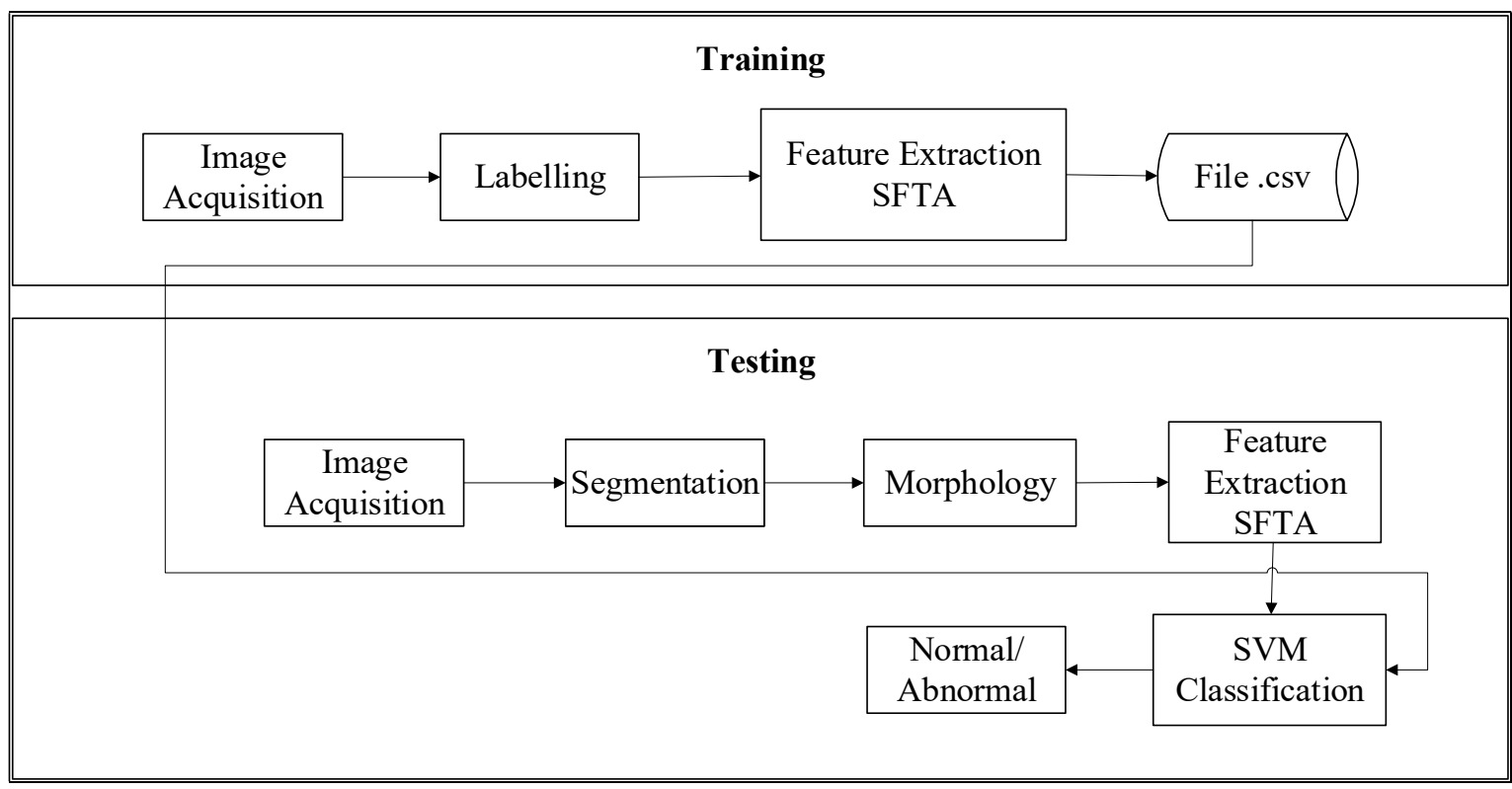

Figure 2. Block Diagram

\section{A. Image Acquisition}

In the image acquisition step, the image is read and save in .pgm or .png file on the computer.

\section{B. Segmentation}

The mammogram image entered into the system in the image acquisition process then carried out the segmentation process. The segmentation stage in this study uses the k-means clustering and thresholding algorithm. K-means is the process of classifying $n$ objects with 
attributes into groups of k, where $k<n$ (Amaliah et al., 2018) (Setiawan \& Putra, 2019). This research used $k=4$, then repeatedly searched the centroid's closest distance. The steps are as follows.

1. Determine the number of clusters $\mathrm{k}$. The value of $k=4$ is used for this process. This value of $k$ is the number of segments generated later where $\mathrm{k}$ is positive.

2. Determine the initial centroid position from the image pixel value with coordinates $f(x, y)$.

3. Calculate the distance between the centroid and other objects using the euclidean distance using Equation (1)

$$
(x, y)=\sqrt{\sum_{i=1}^{n}\left(x_{i}-y_{i}\right)^{2}}
$$

Where:

$$
\begin{array}{ll}
\mathrm{d}(\mathrm{x}, \mathrm{y}) & =\text { Euclidean distance's result } \\
\mathrm{n} & =\text { number of data } \\
\mathrm{x}_{\mathrm{i}} & =\text { data } \mathrm{x} \text { to- } \mathrm{i} \\
\mathrm{y}_{\mathrm{i}} & =\text { data } \mathrm{y} \text { to-i }
\end{array}
$$

4. Pixel grouping is done by assigning image pixels to the nearest cluster between $k$. This closest distance is the smallest value from the euclidean distance results.

5. Update the centroid by calculating the mean of the pixels assigned in the appropriate cluster. Compared with the previous centroid, if the centroid changes, repeat the process three and four until the centroid is stable.

The k-means clustering results are carried out at the thresholding stage with a value of $T=$ 158. The value of each pixel that exceeds or is equal to the pixel value becomes 255 , while if it is below the threshold, it becomes 0 .

\section{Morphology}

The thresholding process results are used as input to the morphological process, namely the form operation, consisting of two arrays. The first array as an image input carried out by the morphological, while the second contains strel or structure element (SE) (Luthfi et al., 2019). The forms of morphological operations used in the digital image process are dilation, erosion, opening, and closing. The morphology used in this study is opening.

The first opening stage is the erosion process, which then continued with the dilation process. The strel process has been determined and matched with each pixel input of the binary image. Each pixel is placed with the axis point. The strel used in this study is $15 \times 15$ in size with a square shape.

1. Erosion is the process of thinning or shrinking the edges of a pixel by changing the value to 0 or background pixels on the coordinate axis point of the object image that neighbors outside part of the strel,

2. The erosion results obtained then continued to the dilation process, which is the opposite of the erosion process by thickening or enlarging the pixels' edges. A pixel that is crushed with a strel will have a 255 or white axis center.

Masking is performed to the result of opening processes to return the pixel value to the original image acquisition process. The flowchart of the morphology can be seen in Figure 4. 


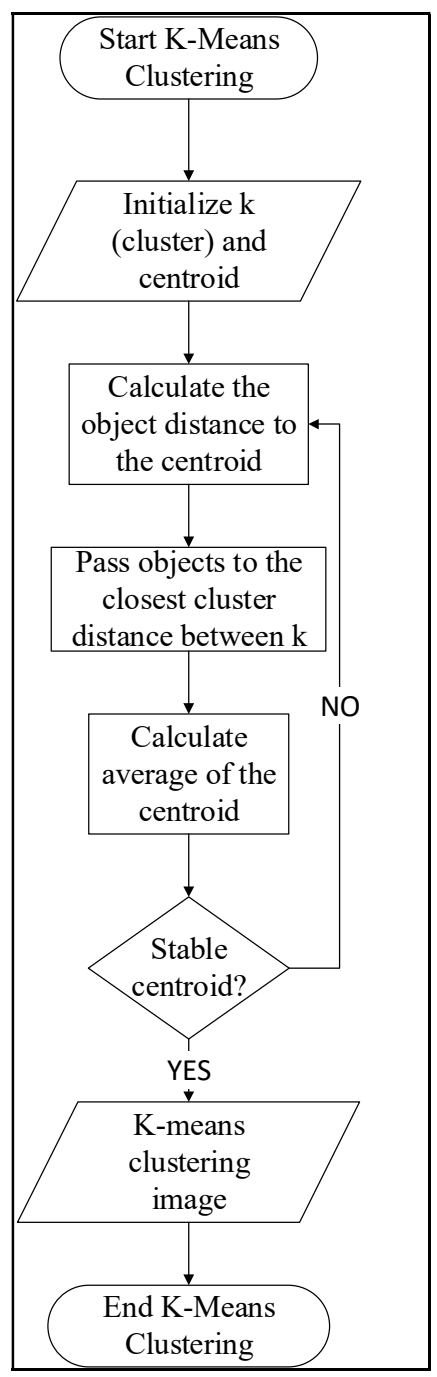

Figure 3. Flowchart of K-Means Clustering

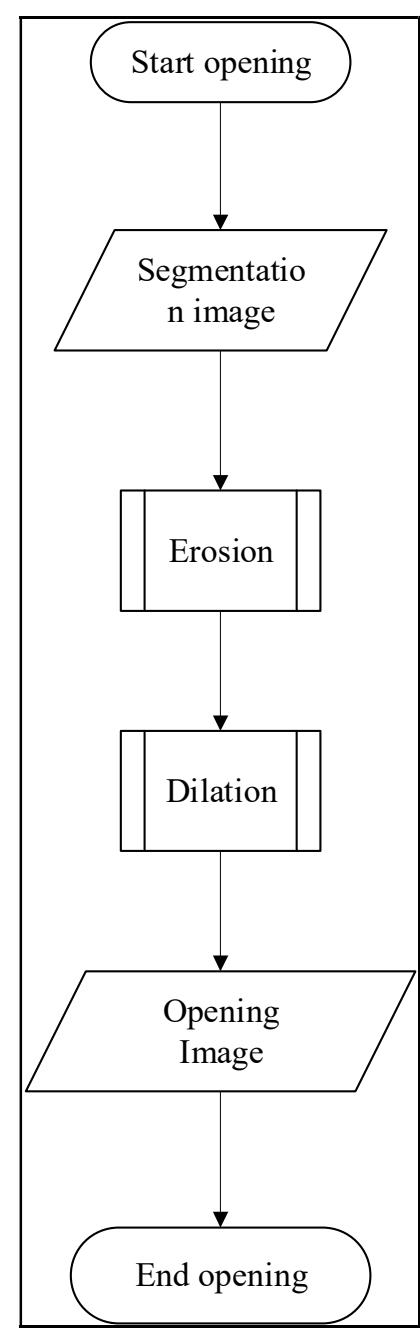

Figure 4. Flowchart of Morphology

\section{Texture Feature Extraction}

The results of the morphological stage then go through the texture feature extraction process. Texture-based feature extraction is an example of the GLCM method, but this method has the disadvantages of high error rates, long execution processes, and low classification accuracy (Edwin et al., 2017). This study uses the SFTA feature extraction method for fractal feature extraction (Ergen \& Baykara, 2014). The process of this method is divided into two parts. The first is the Two Threshold Binary Decomposition (TTBD) process in the gray image, converted into a different binary image. The second stage is the feature extraction stage of each binary image, namely obtaining the fractal dimension, mean, and area. In the TTBD algorithm's first stage, the $T$ threshold value is calculated using multilevel otsu thresholding (Usha \& Perumal, 2019). The threshold value is chosen based on the smallest within-class variance (Paramkusham et al., 2018). The Otsu algorithm is applied to each image until the threshold amount reaches the nt (number of holding) value using Equation (2) and Equation (3). 


$$
\begin{aligned}
& I_{b 1}(x, y)=\left\{\begin{array}{c}
1, \text { If } I(x, y) \geq t_{I} \\
0, \text { if not }
\end{array}\right. \\
& I_{b 2}(x, y)=\left\{\begin{array}{r}
1, \text { if } t_{I}<I(x, y) \leq t_{u} \\
0, \text { if not }
\end{array}\right.
\end{aligned}
$$

The number of holding is a user-defined parameter used in this study, namely $n t=3$. Equation 2 is the first set, and equation 3 is the second set to produce a binary image.

Where:

$$
\begin{array}{ll}
x & =\text { matrix row } \\
y & =\text { matrix column } \\
t_{I} & =\text { gray lower boundary } \\
t_{u} & =\text { gray upper boundary } \\
I(x, y) & =\text { gray image } \\
I_{b}(x, y) & =\text { binary image }
\end{array}
$$

The number of a series of binary images produced is $2 * n t$ (number of thresholding). Equation 4 is used to determine the boundaries of the binary image used to find the fractal dimension value.

$$
\Delta(x, y)=\left\{\begin{array}{c}
255, \text { if } \exists\left(x^{\prime}, y\right) \in N_{\mathcal{B}}[(x, y)]: \\
I_{b}\left(x^{\prime}, y\right)=0 \cap I_{b}\left(x^{\prime}, y\right)=255 \\
0, \text { if not }
\end{array}\right.
$$

Where:

$$
\begin{array}{ll}
x & =\text { matrix raw } \\
y & =\text { matrix column } \\
N_{8}[(x, y)] & =8 \text { pixel connected to }(x, y) \\
I_{b}(x, y) & =\text { binary image } \\
\Delta(x, y) & =\text { binary image boundary }
\end{array}
$$

The boundary of the binary image is used to find the fractal dimension value. This value is obtained using box-counting (El-henawy et al., 2016) to cover the input image with a box shape and count how many squares cover the image, and repeat it a pattern structure is formed (Shanmugavadivu et al., 2017).

\section{E. Classification}

The classification process produces feature extraction from the mammogram by comparing the test data with the training data feature's characteristics. Creating a model from training data using a Support Vector Machine (SVM) is a machine learning method used for the classification or regression process to find the best hyperplane that separates two classes (Setiawan \& Putra, 2019). Comparing the test data features with the model made. The classification results will determine the class of the tested mammogram image with the output in normal images for those in the negative area or abnormal for the positive area. 


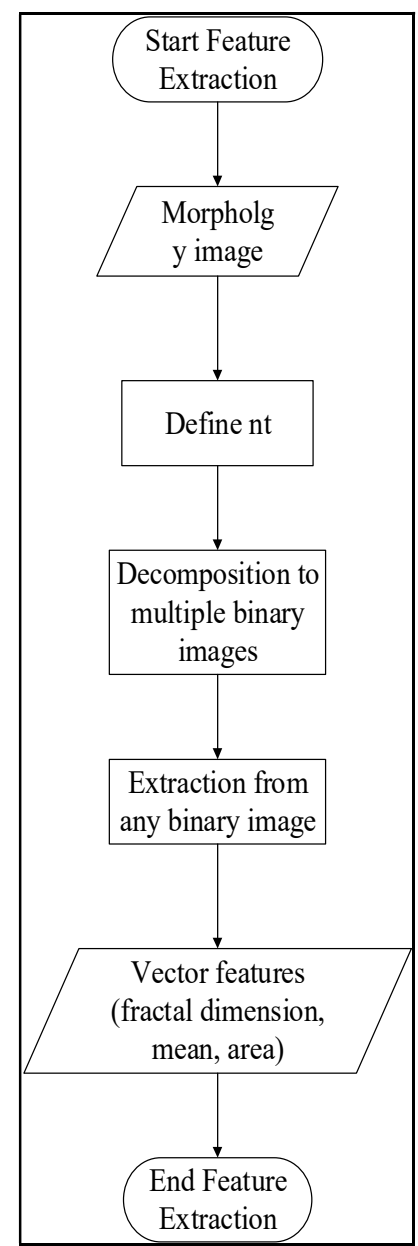

Figure 5. Flowchart of Feature Extraction

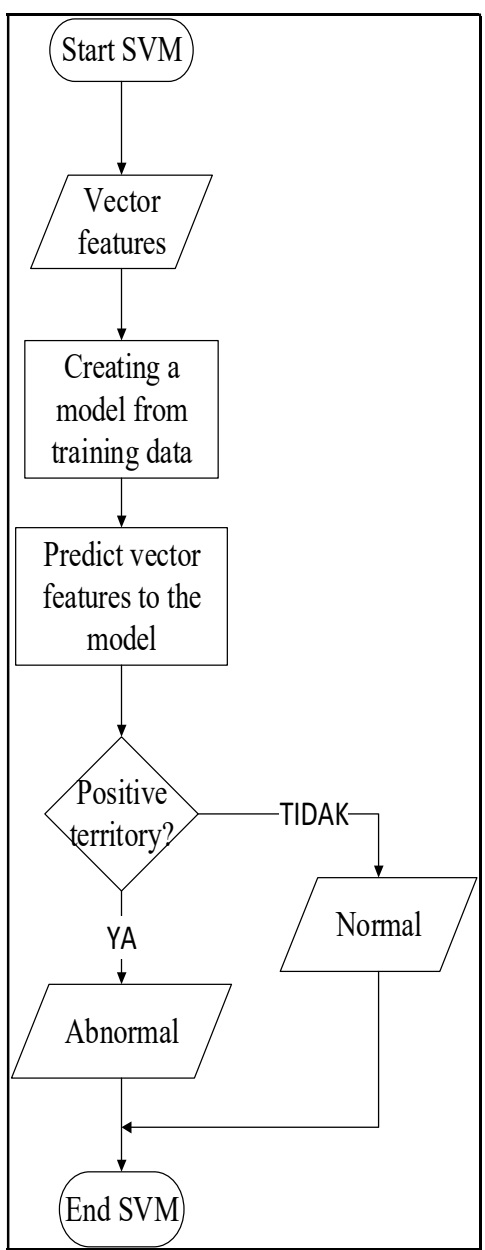

Figure 6. Flowchart of Classification

\section{RESULT AND DISCUSSION}

This section describes each stage's results in this study on the system created to produce accuracy from applying the SFTA method. The test results were obtained by calculating the accuracy in Equation (5), precision in Equation (6), recall in Equation (7), and fi-score value in Equation (8).

$$
\begin{gathered}
\text { Accuracy }=\frac{T P+T N}{T P+F P+F N+T N} \times 100 \% \\
\text { Precision }=\frac{T P}{T P+F P} \times 100 \% \\
\text { Recall }=\frac{T P}{T P+F N} \times 100 \% \\
\text { F1-score }=2 \times \frac{\text { Precision } \times \text { Recall }}{\text { Precision } \times \text { Recall }} \times 100 \%
\end{gathered}
$$


Where:

$T P=$ True Positive

$F P=$ False Positive

$T N=$ True Negative

$F N=$ False Negative

\section{Labeling}

Labeling the first stage of this research is for the data training process. The abnormal image mass is marked with pixel coordinates $(x, y)$ and radius in this stage. Coordinates and radius are obtaining from the dataset. The results of the labeling stage are shown in Figure 7 . The next step process, the texture feature extraction process for each labeling image using SFTA and then stored in .csv containing vector features with the fractal dimension, mean, and area values.

\section{Segmentation}

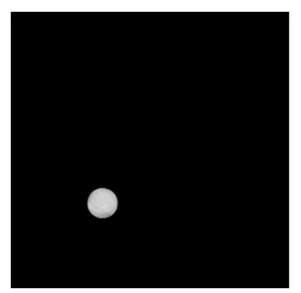

Segmentation aims to separate the mass object indication from the background using k-means clustering and then proceed with the thresholding process. The k-means clustering stage in this study uses the $k=4$ value, and for thresholding, it uses the $T=158$ value. The $k=4$ value is the optimal value, it can be seen from the test results in Table 1 , and the $T=158$ value is the optimal value, it can be seen in Table 2 .

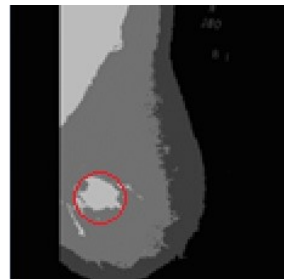

(a) K-means clustering

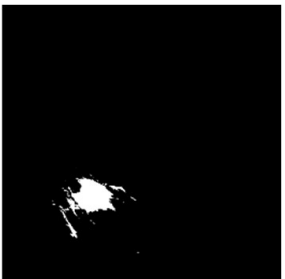

(b) Thresholding

Table 1. Testing of K Value (Cluster)

\begin{tabular}{|c|c|}
\hline $\mathbf{K}$ & Accuracy(\%) \\
\hline 3 & 66,33 \\
\hline 4 & 73,33 \\
\hline 5 & 70 \\
\hline 6 & 70 \\
\hline
\end{tabular}

Table 2.Testing of T Value (Threshold)

\begin{tabular}{|c|c|}
\hline $\mathbf{T}$ & Accuracy(\%) \\
\hline 138 & 56,67 \\
\hline 158 & 73,33 \\
\hline 178 & 63,33 \\
\hline 198 & 56,67 \\
\hline
\end{tabular}


The segmentation test results for the $k$ value (cluster) of the k-means process in Table 1 start from $k=3$, because the $k=1$ image value is only a black background, while $k=2$ is only the background and outer part of the breast. The result of the optimal value of $k=4$ can classify the mass with an accuracy of $73.33 \%$, having the highest value compared to other $k$ values

The next segmentation process uses thresholding. Testing the $T$ value for thresholding starts from $T=138$ because the mammogram image's mass has a bright color, meaning that the value of the pixel intensity is relatively high. The value of $T=158$ is optimal based on the test in Table 2, with an accuracy of $73.33 \%$, having the highest value compared to other $T$ values.

\section{Morphology}

The morphology at this stage aims to remove small pixels using the opening. In this study, use a square size of $15 \times 15$. A masking process then follows the morphology results to restore the pixel value of the image. The results of the morphology and masking image are shown in Figure 9.

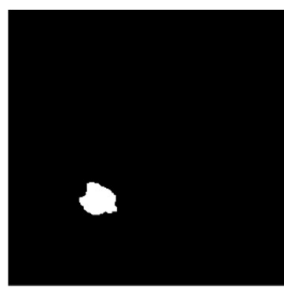

(a) Opening Figure 9. Morphology's result

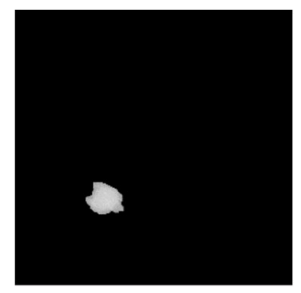

(b) Masking

\section{SFTA Feature Extraction}

The SFTA method in this study is used to extract the mammogram mass's texture features to produce vector features that contain the fractal dimension, mean, and area values. This research used $n t=3$ as an input parameter to the SFTA method. The value of $n t=3$ is the optimal value with an accuracy of $90 \%$; the test can be seen in Table 3 .

Table 3. Testing of Nt Value (Number of Thresholds)

\begin{tabular}{|c|c|}
\hline $\mathbf{N t}$ & Accuracy(\%) \\
\hline 1 & 63,33 \\
\hline 2 & 73,33 \\
\hline 3 & 90 \\
\hline 4 & 83,33 \\
\hline 5 & 83,33 \\
\hline 6 & 80 \\
\hline 7 & 86,67 \\
\hline 8 & 80 \\
\hline 9 & 76,67 \\
\hline 10 & 70 \\
\hline
\end{tabular}

Table 4. Range Value of Training Data

\begin{tabular}{|c|c|c|c|}
\hline Class & D & $(\bar{v})$ & A \\
\hline Normal & 0 atau 1,15-1,34 & 0 atau $55,874-162,32$ & 0 atau $4498,44-14165,16$ \\
\hline Abnormal & $0,098-0,97$ & $8,27-164,4$ & $117,57-878,19$ \\
\hline
\end{tabular}

Table 3 describes the optimal nt value test at $n t=3$ with an accuracy of $90 \%$ supported by the segmentation process's optimal value. The value of $n t=3$ produces six different binary images. Each binary image has 3 features, namely the fractal dimension, mean, and area. The 
total features resulting from $n t=3$ are 18 features. The number of features produced by SFTA did not make the accuracy get any higher.

Based on the extraction process of 215 normal class training images and 185 abnormal class images using the SFTA method with the optimal nt value, $n t=3$, then the results of the range of normal and abnormal values are obtained for the fractal dimension (D), mean $(\bar{v})$, and area (A) as shown in Table 4.

Table 4 explains the range of classes of the training data values, namely normal and abnormal. The normal class has no mass in the mammogram image, while the abnormal one is a class mass on the mammogram image. The test results show that the three values of fractal dimension, mean, and area on abnormal class have a smaller range of values than the normal class. These three values are obtained by adding up the binary image features per group and dividing by 215 for normal images and 185 for abnormal images. The final stage takes the minimum and maximum values of the three values.

\section{Training}

At this stage, validating the training data with input parameters from texture feature extraction from the SFTA method is performed. The validation set aims to provide a model evaluation from training data to support the test data.

Table 5. Validation Set

\begin{tabular}{|c|c|c|c|c|}
\hline Nt & Accuracy(\%) & Precision(\%) & Recall(\%) & $\begin{array}{c}\text { F1- } \\
\text { Score(\%) }\end{array}$ \\
\hline 1 & 99,17 & 99,28 & 99 & 99,13 \\
\hline 2 & 99,17 & 98,28 & 99 & 99,13 \\
\hline 3 & 98,33 & 98,25 & 98,25 & 98,25 \\
\hline 4 & 99,17 & 98,28 & 99 & 99,13 \\
\hline 5 & 97,5 & 98,21 & 96,49 & 97,35 \\
\hline 6 & 96,67 & 94,49 & 98,25 & 96,55 \\
\hline 7 & 94,17 & 94,64 & 92,98 & 93,81 \\
\hline 8 & 95 & 96,36 & 92,98 & 94,64 \\
\hline 9 & 94,17 & 96,3 & 91,23 & 93,69 \\
\hline 10 & 93,33 & 96,23 & 89,47 & 92,73 \\
\hline
\end{tabular}

The training data covers the fractal dimension, mean, and area features extracted using SFTA. Many features are generated depending on the $n t$ parameter used. These value results are obtained from dividing training data and test data with training data by $70 \%$ and testing data by $30 \%$. Table 5 shows the highest accuracy, precision, recall, and f1-score, respectively, $99.17 \%, 99.28 \%, 99 \%$, and $99.13 \%$.

\section{Testing}

At this stage, the feature extraction result processed using a Support Vector Machine for classifying the normal and abnormal cases. At the testing stage, about 30 images were tested consist of 15 abnormal and 15 normal images. The form of the tested image is in .pgm for the MIAS source and .png for the CBIS-DDSM source. The image size tested was $1024 \times 1024$, according to the dataset from the two image sources. 
Table 6. The system testing

\begin{tabular}{|c|c|c|c|}
\hline No & Test Image & Result of Classification & Explanation \\
\hline 1 & Abnormal & Abnormal & True(TP) \\
\hline 2 & Abnormal & Abnormal & True (TP) \\
\hline 3 & Normal & Normal & True (TN) \\
\hline 4 & Abnormal & Abnormal & True (TP) \\
\hline 5 & Abnormal & Abnormal & True (TP) \\
\hline 6 & Abnormal & Abnormal & True (TP) \\
\hline 7 & Normal & Normal & True (TN) \\
\hline 8 & Normal & Normal & True (TN) \\
\hline 9 & Abnormal & Abnormal & True (TP) \\
\hline 10 & Normal & Normal & True (TN) \\
\hline 11 & Normal & Normal & True (TN) \\
\hline 12 & Abnormal & Abnormal & True (TP) \\
\hline 13 & Abnormal & Abnormal & True (TP) \\
\hline 14 & Abnormal & Abnormal & True (TP) \\
\hline 15 & Normal & Normal & True (TN) \\
\hline 16 & Normal & Normal & True (TN) \\
\hline 17 & Abnormal & Normal & False (FN) \\
\hline 18 & Normal & Normal & True(TN) \\
\hline 19 & Normal & Abnormal & False (FP) \\
\hline 20 & Normal & Normal & True (TN) \\
\hline 21 & Normal & Abnormal & False (FP) \\
\hline 22 & Abnormal & Abnormal & True (TP) \\
\hline 23 & Abnormal & Abnormal & True (TP) \\
\hline 24 & Abnormal & Abnormal & True (TP) \\
\hline 25 & Normal & Normal & True (TN) \\
\hline 26 & Normal & Normal & True (TN) \\
\hline 27 & Abnormal & Abnormal & True (TP) \\
\hline 28 & Abnormal & Abnormal & True (TP) \\
\hline 29 & Normal & Normal & True (TN) \\
\hline 30 & Normal & Normal & True (TN) \\
\hline & & & \\
\hline
\end{tabular}

The system testing results are shown in Table 6 using optimal values of $k=4, T=158$, and $n t=3$. The images tested were the different images as the training data. Classification errors occur in images with numbers 17,19 , and 21 . The error on number 17 occurred when segmentation cannot find the mass so that during the extraction process, the three values of fractal dimension, mean, and area are zero. The errors for numbers 19 and 21 occurred during the classification process. The value of the resulting feature extraction from number 19 and 21 belong to an abnormal class. To overcome these misclassifications from the system model created, the author added a new segmentation process. In other words, the writer did the preprocessing stage first and adding new training data so that the fractal dimension, mean, and area values can cover the entire abnormal class.

Table 7. Confusion Matrix

\begin{tabular}{|c|c|c|}
\hline Classification & Abnormal & Normal \\
\hline Abnormal & $14(\mathrm{TP})$ & $2(\mathrm{FP})$ \\
\hline Normal & $1(\mathrm{FN})$ & $13(\mathrm{TN})$ \\
\hline
\end{tabular}

Table 7 is a confusion matrix made to test the accuracy calculation, precision, recall, and f1score values easier. The system test results can correctly classify 14 images of abnormal images; two images are misclassified as abnormal images. One image is misclassified, it should be normal images, and 13 images were classified correctly. 


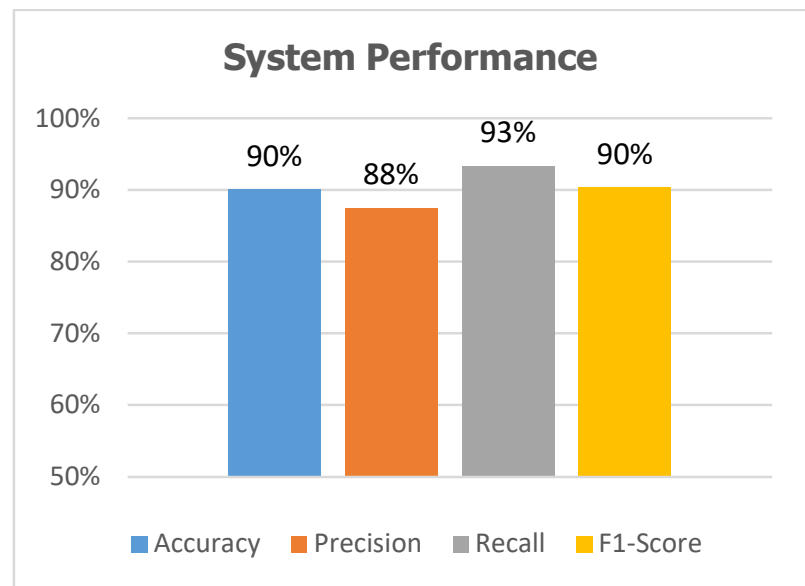

Figure 10. System Performance Graph

This system test results using the SFTA method show accuracy, precision, recall, and f1-score, respectively $90 \%, 87.5 \%, 93.33 \%$, and $90.32 \%$ with input $n t=3$. Based on the results of the validation set and performance testing of the mass detection system on the mammogram image, underfitting or overfitting conditions did not occur because the resulting accuracy was not too much different at the percentage of $90 \%$.

\section{CONCLUSION}

Based on performance testing of the system using the Segmentation-based Fractal Texture Analysis (SFTA) method to detect cancer cells, the system can classify mammogram images with an accuracy percentage of $90 \%$, a precision of $87.75 \%$, a recall of $93.33 \%$, and $\mathrm{f1}$-score of $90.32 \%$. Using $k$ value in the $k$-means clustering process is $k=4$, thresholding $T=158$, and feature extraction using SFTA with $\mathrm{nt}=3$ could reach the highest result of this research.

\section{REFERENCES}

Amalia, A. E., Airlangga, G., \& Thohari, A. N. A. (2018). Breast Cancer Image Segmentation Using K-Means Clustering Based on GPU Cuda Parallel Computing. Jurnal Infotel, 10(1), 33-38. https://doi.org/10.20895/infotel.v10i1.344

Arafah, A. B. R., \& Notobroto, H. B. (2017). Faktor Yang Berhubungan dengan Perilaku Ibu Rumah Tangga Melakukan Pemeriksaan Payudara Sendiri (Sadari). Ijph, 12, 143-153. https://doi.org/10.20473/ijph.v12i1.2017.143-153

Biswas, R., Nath, A., \& Roy, S. (2016). Mammogram classification using gray-level cooccurrence matrix for diagnosis of breast cancer. Proceedings - 2016 International Conference on Micro-Electronics and Telecommunication Engineering, (pp. 161-166).

Costa, A. F., Humpire-Mamani, G., \& Traina, A. J. M. H. (2012). An efficient algorithm for fractal analysis of textures. Brazilian Symposium of Computer Graphic and Image Processing, 39-46. https://doi.org/10.1109/SIBGRAPI.2012.15 
El-henawy, I., Bakry, H. M. El, \& Hadad, H. M. El. (2016). Cattle Identification Using Segmentation-based Fractal Texture Analysis and Artificial Neural Networks. Int. J. of $\begin{array}{llll}\text { Electronics and Information } & \text { Engineering, }\end{array}$ https://doi.org/10.6636/IJEIE.201606.4(2).04

Ergen, B., \& Baykara, M. (2014). Texture based feature extraction methods for content-based medical image retrieval systems. Bio-Medical Materials and Engineering, 24(6), 30553062. https://doi.org/10.3233/BME-141127

Fajrin, H. R., Nugroho, H. A., \& Soesanti, I. (2015). Ekstraksi Ciri Berbasis Wavelet Dan Glcm Untuk Deteksi Dini Kanker Payudara Pada Citra Mammogram. Snst, 47-52.

Hariraj, V., Wan, K., Vikneswaran, \& Zunaidi, I. (2017). An efficient data mining approaches for breast cancer detection and segmentation in mammogram. Journal of Advanced Research in Dynamical and Control Systems, 9(Special Issue 3), 185-194.

Junita, B. D. (2017). Ekstraksi Fitur dan Klasifikasi Menggunakan Metode GLCM dan SVM pada Citra Mammogram untuk identifikasi Kanker Payudara. 22(1), 18-26.

Larasati, B. A., \& Prawira, A. (2018). Perbandingan Berbagai Teknologi untuk Mencari Dan Deteksi Kanker Payudara: Article Review. 16, 213-221.

Listia, R., Harjoko, A., Mada, U. G., \& Utara, S. (2014). Klasifikasi Massa pada Citra Mammogram Berdasarkan Gray Level Cooccurence Matrix (GLCM). IJCCS (Indonesian Journal of Computing and Cybernetics Systems), $8(1)$, 59-68. https://doi.org/10.22146/ijccs.3496

Luthfi, M., Amin, I. H. Al, \& Cahyono, T. D. (2019). Penghalusan Kontur dan Tepi Obyek Citra Menggunakan Operasi Opening dan Closing. Proceeding SINTAK 2019, (pp. 352-360).

M, A. K., Edwin, D., Hariharan, S., \& Student, M. T. (2017). Liver Tumor Segmentation and Feature Extraction using Segmentation based Fractal Textural Analysis Method ( SFTA ). International Journal of Advanced Scientific Technologies, Engineering and Management Sciences, (1), 169-172.

Nababan, E. B., Iqbal, M., \& Rahmat, R. F. (2017). Breast cancer identification on digital mammogram using Evolving Connectionist Systems. 2016 International Conference on Informatics and Computing, (pp. 132-136).

Nur, I. M. (2014). Mammography Screening pada Kanker Payudara dengan Generalized Structured Component Analysis. Universitas Muhammadiyah Semarang, 2(1).

Öztürk, Ş., \& Akdemir, B. (2018). Application of Feature Extraction and Classification Methods for Histopathological Image using GLCM, LBP, LBGLCM, GLRLM and SFTA. Procedia Computer Science, 132(Iccids), 40-46. https://doi.org/10.1016/j.procs.2018.05.057 
Paramkusham, S., Rao, K. M. M., \& Prabhakar Rao, B. V. V. S. N. (2018). Comparison of rotation invariant local frequency, LBP and SFTA methods for breast abnormality classification. International Journal of Signal and Imaging Systems Engineering, 11(3), 136-150. https://doi.org/10.1504/IJSISE.2018.093266

R. Suresh, A. N. Rao, dan B. E. Reddy. (2019). Detection and classification of normal and abnormal patterns in mammograms using deep neural network. Concurr. Comput., vol. 31, no. 14, hal. 1-12, 2019.

Setiawan, K. N., \& Putra, I. S. (2018). Klasifikasi Citra Mammogram Menggunakan Metode. MERPATI VOL. 6, NO. 1, , 13-24.

Shanmugavadivu, P., Krishnaveni, A., Sivakumar, V., \& Narayanan, S. G. L. (2017). Digital Mammogram Segmentation and Feature Extraction: A Review. 9(12), 701-705.

Supriyanti, E. (2014). Perbandingan Ekstraksi Ciri Pada Data Mammogram Untuk Identifikasi Mikrokalsifikasi. SIMETRIS, 5(2), 153-160.

Usha, R., \& Perumal, K. (2019). Morphological Transformation Based Fractal Texture Segmentation of MR Brain Tumour Image Slices. Ijaiem, \&(1), 1-7 